GeoScienceEd 1(2) (2020)
Jurnal Pendidikan, Sains, Geologi dan Geofisika
Journal of Education, Science, Geology and Geophysics
https://jpfis.unram.ac.id/index.php/GeoScienceEdu

\title{
Peningkatan Hasil Belajar IPA melalui Penerapan Metode Group Investigation
}

\author{
Roslaini ${ }^{*}$ \\ ${ }^{1}$ Sekolah Menengah Pertama Negeri 4 Dumai, Riau, Indonesia.
}

DOI: https:// doi.org/10.29303/goescienceedu.v1i2.55

\section{Article Info}

Received : 24 Agustus 2020

Revised : 15 December 2020

Accepted: 23 Desember 2020

\begin{abstract}
Abstrak: Tujuan penelitian tindakan kelas ini adalah untuk meningkatkan hasil belajar IPA siswa memalui penerapan metode group investigation pada siswa kelas IX-2 SMP Negeri 4 Dumai tahun pelajaran 2019/2020. Penelitian ini dilaksanakan di kelas IX-2 SMP Negeri 4 Dumai pada semester genap tahun pembelajaran 2019/2020. Penelitian ini dimulai dari bulan Januari 2020 sampai dengan bulan Februari 2020. Subjek penelitian ini adalah siswa kelas IX-2 SMP Negeri 4 Dumai sebanyak 32 orang siswa, yakni terdiri dari 18 orang siswa laki-laki dan 14 orang siswa perempuan dengan kemampuan yang heterogen. Bentuk penelitian ini adalah Penelitian Tindakan Kelas (PTK). Hasil penelitian ini menunjukkan bahwa penerapan metode group investigation dapat meningkatkan hasil belajar IPA pada pada siswa kelas IX-2 SMP Negeri 4 Dumai tahun pelajaran 2019/2020. Hasil belajar sebelum PTK adalah 62.8 dengan kategori kurang. Pada siklus I hasil belajar siswa memperoleh ratarata 74.5 dengan kategori cukup. Pada siklus II mengalami peningkatan hasil belajar siswa menjadi 81.0 dengan kategori baik.
\end{abstract}

Kata Kunci: group investigation; hasil belajar; Ilmu Pengetahuan Alam

Abstract: The purpose of this classroom action research was to find out that the application of the group investigation method in class IX-2 students of SMP Negeri 4 Dumai in the 2019/2020 academic year. This research was conducted in class IX-2 of SMP Negeri 4 Dumai in the even semester of the 2019/2020 learning year. This research was started from January 2020 to February 2020. The subjects of this study were 32 students of class IX-2 of SMP Negeri 4 Dumai, consisting of 18 men and 14 women with heterogeneous abilities. The form of this research is Classroom Action Research (CAR). The results of this study indicate that the application of the group investigation method can improve science learning outcomes in class IX-2 students of SMP Negeri 4 Dumai in the 2019/2020 academic year. The learning outcomes before CAR was 62.8 with a poor category. In the first cycle the student learning outcomes obtained an average of 74.5 in the sufficient category. In the second cycle, there was an increase in student learning outcomes to 81.0 in the good category.

Keywords: group investigation; learning outcomes; Science

\section{Pendahuluan}

Belajar merupakan suatu proses pengaitan pengetahuan baru pada struktur kognitif yang sudah dimiliki peserta didik. Hal ini mempunyai arti bahwa di dalam proses pembelajaran, peserta didik akan menghubung-hubungkan pengetahuan atau ilmu yang telah tersimpan dalam memorinya kemudian menghubungkan dengan pengetahuan yang baru. Hal ini sesuai dengan pendapat Yatim (2009). Dengan kata lain, belajar adalah suatu proses untuk mengubah performansi yang tidak terbatas pada keterampilan, tetapi juga meliputi fungsi- fungsi seperti skill, persepsi, emosi, proses berpikir, sehingga dapat menghasilkan perbaikan performansi. 
Tercapainya suatu hasil yang optimal tergantung oleh kegiatan siswa atau anak didik itu sendiri. Dengan kata lain, tercapainya tujuan pembelajaran itu sangat dipengaruhi oleh bagaimana aktifitas siswa didalam belajar. Namun, harus juga diingat sesuai dengan uraian diatas meskipun tujuan pembelajaran itu dirumuskan secara jelas dan baik, belum tentu hasil pembelajaran yang diperoleh optimal. Karena hasil yang baik itu dipengaruhi oleh komponen-komponen yang lain, terutama bagaimana aktivitas siswa sebagai subjek belajar (Sardiman, 2012).

Salah satu komponen yang mempengaruhi hasil belajar siswa adalah pemilihan model dan metode pembelajaran yang sesuai dengan tujuan pembelajaran yang telah dirumuskan sebelumnya. Menurut Djamarah (2010) bahwa setiap model pembelajaran yang digunakan bertalian dengan tujuan belajar yang ingin dicapai. Model pembelajaran dapat menjadi indikator tercapainya sebuah kegiatan belajar mengajar.

Di dalam pembelajaran IPA di kelas IX-2 SMP Negeri 4 Dumai, pemilihan model dan metode pembelajaran cenderung hampir sama pada setiap pertemuannya. Metode ceramah lebih mendominasi di dalam proses pembelajaran IPA. Hal ini menimbulkan kebosanan dan kejenuhan pada siswa di dalam mengikuti proses pembelajaran IPA sehingga berdampak pada hasil belajar siswa yang menurun. Hal ini dapat diketahui dari jumlah siswa yang mencapai KKM pada saat dilaksankannya ulangan harian yang hanya mencapai $56.3 \%$.

Selama ini proses belajar mengajar yang diterapkan oleh guru bersifat satu arah. Hanya terjadi transfer ilmu dari guru ke siswa tanpa ada interaksi siswa secara langsung. Proses pembelajaran seperti ini harus diperbaiki. Di dalam interaksi proses belajar mengajar di kelas, guru memegang kendali utama untuk keberhasilan tercapainya tujuan pembelajaran. Diperlukan suatu pembaharuan dan perbaikan di dalam proses pembelajaran agar tujuan pembelajaran dapat tercapai dengan baik dan hasil belajar siswa juga dapat meningkat. Salah satu pembaharuan dan perbaikan yang dapat dilakukan adalah melalui penerapan metode group investigation.

Menurut Huda (2013) bahwa group investigation adalah suatu metode pembelajaran yang menekankan pada pilihan dan kontrol siswa daripada menerapkan teknik-teknik pengajaran di ruang kelas. Selain itu juga memadukan prinsip belajar demokratis dimana siswa terlibat secara aktif dalam kegiatan pembelajaran baik dari tahap awal sampai akhir pembelajaran.
Metode group investigation seringkali disebut sebagai metode pembelajaran kooperatif yang paling kompleks. Hal ini disebabkan oleh metode ini memadukan beberapa landasan pemikiran, yaitu berdasarkan pandangan konstruktivistik, democratic teaching, dan kelompok belajar kooperatif. Berdasarkan pandangan konstruktivistik, proses pembelajaran dengan metode group investigation memberikan kesempatan seluas-luasnya kepada siswa untuk terlibat secara langsung dan aktif dalam proses pembelajaran mulai dari perencanaan sampai cara mempelajari suatu topik melalui investigasi (Budimansyah, 2012).

Suprijono (2016) mengemukakan bahwa dalam penggunaan metode group investigation setiap kelompok akan bekerja untuk melakukan investigasi sesuai dengan masalah yang mereka pilih. Sesuai pendapat ersebut dapat diketahui bahwa pembelajaran dengan metode group investigation adalah pembelajaran yang melibatkan aktivitas siswa dan tentu akan membangkitkan semangat serta motivasi siswa untuk belajar.

Hasil belajar merupakan perubahan prilaku yang relatif mantap dalam diri seseorang sebagai akibat dari interaksi seseorang dengan lingkungannya. Hasil belajar memiliki beberapa ranah atau kategori dan secara umum merujuk kepada aspek pengetahuan, sikap dan keterampilan (Uno, 2011).

\section{Metode}

Penelitian ini dilaksanakan di kelas IX-2 SMP Negeri 4 Dumai pada semester genap tahun pembelajaran 2019/2020. Penelitian ini dimulai dari bulan Januari 2020 sampai dengan bulan Februari 2020. Subjek penelitian ini adalah siswa kelas IX-2 SMP Negeri 4 Dumai sebanyak 32 orang, yang terdiri dari 18 orang siswa laki-laki dan 14 orang siswa perempuan dengan kemampuan yang heterogen.

Penelitian ini merupakan Penelitian Tindakan Kelas (PTK). Berikut diuraikan prosedur penelitian yang telah dilaksanakan dalam dua siklus pada penelitian ini:

1. Perencanaan

Menyiapkan dokumen rencana pembelajaran berupa Rencana Pelaksanaan Pembelajaran (RPP).

2. Tahap Pelaksanaan

Penerapan langkah-langkah metode group investigation yaitu: 
Tabel 1. Tahap Pelaksanaan Metode Group Investigation

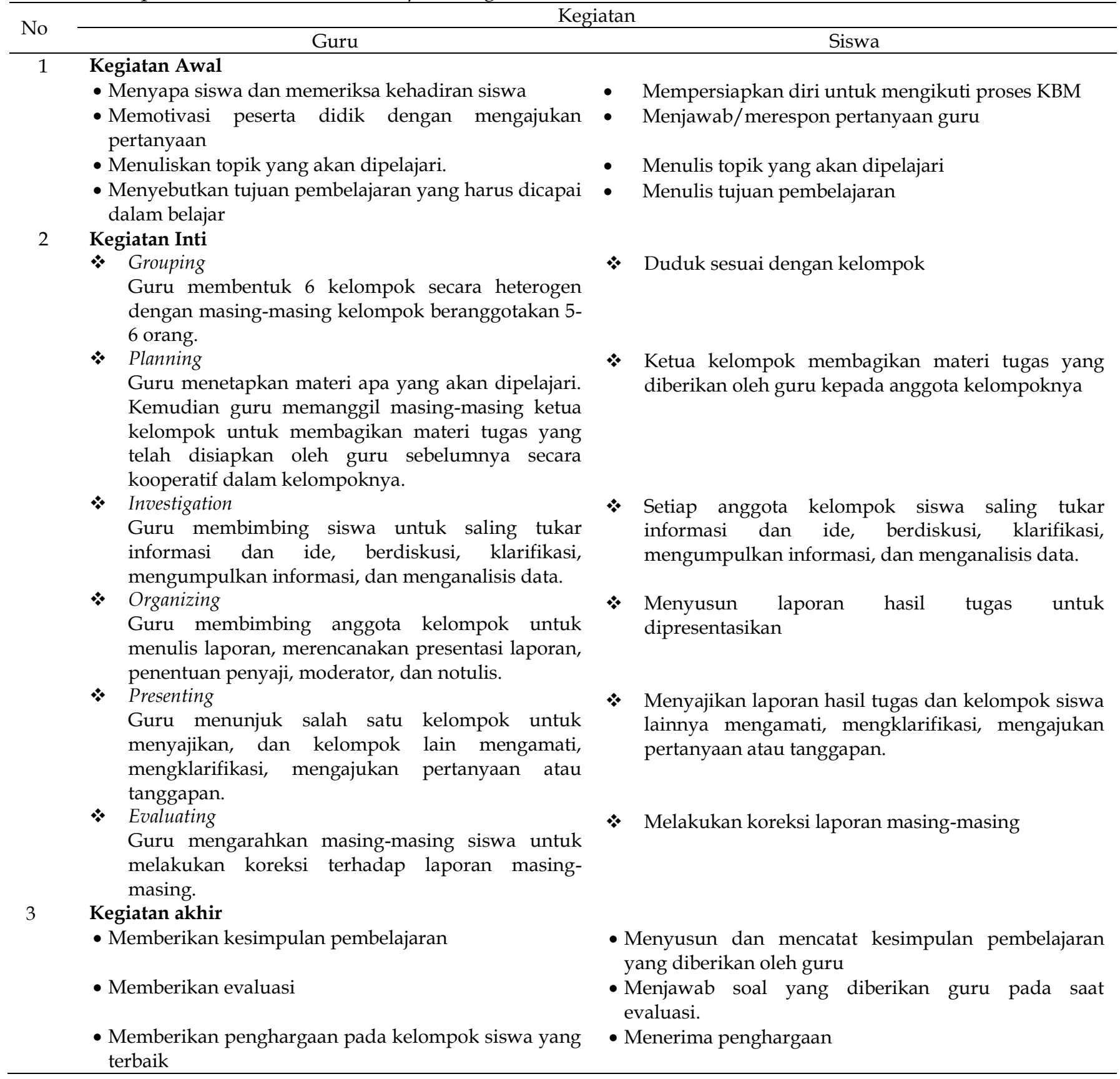

\section{Tahap Observasi}

Hal-hal yang diamati adalah aktivitas guru dan aktivitas siswa.

\section{Refleksi}

Tahap refleksi meliputi proses analisis hasil pembelajaran dan penyusunan rencana perbaikan untuk pembelajaran berikutnya.

\section{Hasil Dan Pembahasan}

Hasil belajar IPA siswa kelas IX-2 sebelum PTK dapat dilihat pada Tabel 2.
Tabel 2. Hasil Belajar Siswa Sebelum PTK dari Ulangan Harian

\begin{tabular}{llll}
\hline No & Kategori & Jumlah & Keterangan \\
\hline 1 & Rata-rata kelas & 62.8 & Kurang \\
2 & Ketuntasan klasikal & $56.3 \%$ & Tidak tuntas \\
3 & Ketuntasan individu & 18 orang & \\
\hline
\end{tabular}

Berdasarkan tabel 2 dapat dijelaskan bahwa hasil belajar siswa sebelum PTK memperoleh rata-rata kelas hanya 62.8 dengan kategori kurang. Ketuntasan individu hanya 18 orang siswa dari 32 orang siswa. Ketuntasan klasikal sebesar 56.3\%. Hasil belajar 
klasikal dikatakan tuntas apabila jumlah siswa $\geq 85 \%$ yang mencapai KKM.

Rendahnya hasil belajar siswa sebelum PTK ini disebabkan karena penerapan strategi pembelajaran yang dilaksanakan masih belum tepat. Strategi pembelajaran lebih didominasi oleh guru sehingga aktivitas belajar siswa menjadi pasif. Aliran informasi antara siswa dengan guru dan antara siswa dengan siswa belum tercipta dengan optimal.

Setelah dilakukan penelitian diperoleh hasil belajar siswa pada siklus I sebagaimana dapat dilihat pada Tabel 3.

Tabel 3. Hasil Belajar Siklus I

\begin{tabular}{llll}
\hline Siklus & Ketuntasan individu & Ketuntasan kalsikal & Rata-rata kelas \\
\hline I (Pertemuan 1) & 28 & $87.5 \%$ & 73.4 \\
I (Pertemuan 2) & 28 & $87.5 \%$ & 75.6 \\
\hline
\end{tabular}

Berdasarkan Tabel 3 dapat diketahui bahwa pada siklus I pertemuan 1 hasil belajar siswa mengalami peningkatan. Hasil belajar siswa memperoleh rata-rata kelas 73.4 dengan kategori cukup. Ketuntasan individu sebanyak 28 orang siswa dari 32 orang siswa. Ketuntasan klasikalnya sebesar $87.5 \%$ dengan kategori tuntas. Pada siklus I pertemuan 2 hasil belajar siswa mengalami peningkatan. Hasil belajar siswa memperoleh rata-rata kelas 75.6 dengan kategori cukup. Ketuntasan individu sebanyak 28 orang siswa dari 32 orang siswa. Ketuntasan klasikalnya sebesar $87.5 \%$ dengan kategori tuntas.

Refleksi pada siklus I ditemukan permasalahan yaitu peneliti masih belum maksimal di dalam membimbing siswa untuk saling tukar informasi dan ide, berdiskusi, klarifikasi, mengumpulkan informasi, dan menganalisis data. Rencana yang dilakukan peneliti untuk memperbaiki permasalahan pada refleksi siklus I adalah peneliti akan lebih maksimal di dalam mengarahkan dan membimbing siswa agar dapat melakukan pertukaran informasi dan ide, berdiskusi, klarifikasi, mengumpulkan informasi, dan menganalisis data di dalam kelompoknya.

Setelah dilakukan perbaikan pada siklus II, diperoleh hasil belajar siklus II sebagaimana dapat dilihat pada tabel 4 di bawah ini.

Tabel 4. Hasil Belajar Siswa Siklus II

\begin{tabular}{llll}
\hline Siklus & Ketuntasan individu & Ketuntasan kalsikal & Rata-rata kelas \\
\hline II (Pertemuan 3) & 30 & $93.8 \%$ & 79.7 \\
II (Pertemuan 4) & 31 & $96.9 \%$ & 82.2 \\
\hline
\end{tabular}

Berdasarkan tabel 4 dapat diketahui bahwa pada siklus II hasil belajar siswa mengalami peningkatan. Hasil belajar pada pertemuan 3 memperoleh rata-rata kelas 79.7 dengan kategori baik. Ketuntasan individu sebanyak 30 orang siswa dari 32 orang siswa. Ketuntasan klasikalnya sebesar $93.8 \%$ dengan kategori tuntas. Hasil belajar pada pertemuan 4 memperoleh rata-rata kelas 82.2 dengan kategori baik. Ketuntasan individu sebanyak 31 orang siswa dari 32 orang siswa. Ketuntasan klasikalnya sebesar $96.9 \%$ dengan kategori tuntas. Rata-rata hasil belajar pada siklus I adalah 74.5 dan pada siklus II adalah 81.0.

Refleksi yang dilakukan pada siklus II adalah penerapan metode group investigation di dalam proses pembelajaran telah dapat berjalan dengan baik. Peneliti juga telah maksimal di dalam membimbing siswa untuk saling tukar informasi dan ide, berdiskusi, klarifikasi, mengumpulkan informasi, dan menganalisis data. anggota kelompok telah dapat bekerja sama dengan anggota lainnya dengan baik dan fokus. Hasil belajar siswa juga mengalami peningkatan. Rata-rata hasil belajar siswa pada siklus I adalah 74.5 dengan ketegori cukup dan pada siklus II adalah 81.0 dengan kategori cukup terjadi peningkatan sebesar 6.5, sehingga dapat diketahui bahwa penerapan metode group investigation dapat meningkatkan hasil belajar IPA pada siswa kelas IX-2 SMP Negeri 4 Dumai tahun pelajaran 2019/2020. Berdasarkan hasil refleksi PTK siklus II di atas, peneliti tidak melanjutkan siklus selanjutnya, karena hasil yang diperoleh telah sesuai dengan yang diharapkan.

\section{Kesimpulan}

Berdasarkan penelitian yang telah dilaksanakan pada siklus I dan II, maka dapat disimpulkan bahwa: 1) Penerapan metode group investigation dapat meningkatkan hasil belajar IPA pada siswa kelas IX-2 SMP Negeri 4 Dumai tahun pelajaran 2019/2020; 2) Hasil belajar sebelum PTK adalah 62.8 dengan ketuntasan individu 18 orang dan ketuntasan klasikal adalah 56.3; 3) Hasil belajar siklus I pertemuan 1 adalah 73.4 dengan ketuntasan individu 28 orang dan ketuntasan klasikal adalah $87.5 \%$. Hasil belajar siklus I pertemuan 2 adalah 75.6 dengan ketuntasan individu 28 orang dan ketuntasan klasikal adalah $87.5 \%$; 4) Hasil 
belajar siklus II pertemuan 3 adalah 79.7 dengan ketuntasan individu 30 orang dan ketuntasan klasikal adalah $93.8 \%$. Hasil belajar siklus II pertemuan 4 adalah 82.2 dengan ketuntasan individu 31 orang dan ketuntasan klasikal adalah $96.9 \%$.

\section{Daftar Pustaka}

Budimansyah, D. (2012). Pembelajaran Aktif, Kreatif, dan Menyenangkan. Bandung: Genesindo.

Djamarah. (2010). Psikologi Belajar. Jakarta: Rineka Cipta.

Huda, M. (2013). Model-Model Pengajaran dan Pembelajaran. Yogyakarta: Pustaka Pelajar.

Sardiman, A.M. (2012). Interaksi dan Motivasi Belajar Mengajar. Jakarta: Raja Grafindo Persada.

Suprijono, A. (2016). Cooperative Learning: Teori dan Aplikasi Paikem. Yogjakarta: Pustaka Pelajar.

Uno, H. (2011). Teori Motivasi dan Pengukurannya. Jakarta: Bumi Aksara.

Yatim, R. (2009). Metodologi Penelitian Pendidikan. Surabaya: SIC. 